\title{
The three ages of African studies reference works
}

\author{
John McIlwaine *
}

The following reflections came to mind during my work in 2005 and 2006 on producing the revised $2^{\text {nd }}$ edition of my Africa: guide to reference material (Lochcarron: Hans Zell, 2007), hereinafter referred to as my Guide. They also draw upon and recommend for further reading a number of perceptive articles that have been published on Africanist reference works in the last few years.

The emphasis, as in my Guide, will be on reference material other than bibliographies. I have already written in these pages about African studies bibliography (McIlwaine 2001) and Peter Limb in last year's volume gave an elegant 'state-of-the art' account of this field (Limb 2006). The introduction to my Guide argues that while bibliographies of Africa are comparatively well covered by existing lists such as J.D. Pearson, World bibliography of African bibliographies (Oxford: Blackwell, 1975) and Yvette Scheven, Bibliographies for African studies, 1970-1985 (Oxford: Hans Zell, 1988) and Bibliographies for African studies, 1987-1993 (London: Hans Zell, 1994), coverage of other categories of reference works is much less readily available. This lack of coverage is something that both editions of my own work and Al Kagan's Reference guide to Africa: a bibliography of source, $2^{\text {nd }}$ ed., (Lanham, MD: Scarecrow Press, 2005) seek to remedy.

The question that needs to be asked, of course, is: what is meant by 'reference works'? The term is vague, especially when one has specifically excluded bibliographies. The two main defining characteristics are, firstly, that such sources are concerned primarily with providing factual data, rather than interpretation, and secondly, that their arrangement is intended to facilitate rapid consultation, rather than requiring the whole text to be scanned to locate facts. Such tidy guidelines are easy to draw and impossible to maintain. As I note in my Guide, perhaps the first 'reference work' for Africa that would come into many minds would be Lord Hailey's An African survey, discussed further below, which is a volume that accompanies its extensive factual data by equally extensive comment and interpretation, and that is arranged as a straightforward monograph with chapters, rather than having a quick-reference structure. It is also, of course, wrong to suggest that collections of factual information imply no interpretation: the very process of selection of what data to include and what to exclude, and how they should be presented, obviously involves interpretation.

The first edition of my Guide had no limits on the date of publication of titles included, and indeed contained many references to sources published in the $19^{\text {th }}$ century. The new $2^{\text {nd }}$ edition only includes material published since 1938 (the year of Lord Hailey's African survey) but this decision was taken simply to

* Emeritus Professor of the Bibliography of Asia and Africa, University College London. 
make room for more recent material, and for new coverage of sources relating to the earth sciences and the biological sciences. The date limitation in no way affects my view regarding the potential timelessness of reference sources. Older works retain their value for their coverage of data contemporary with publication. They may also never have been succeeded by more modern titles covering the same field, and may remain the only convenient source of reference. Earlier editions of a single source are potentially as valuable as later editions. A major problem for researchers is that libraries often dispose of older editions of a reference work when a new edition appears, seeing the earlier edition as no longer justifying its expensive shelf space. They are more likely to look at, say, the $85 \%$ of material that is common to each edition or volume and argue for relegation, rather than at the $15 \%$ which is unique. This becomes particularly acute with sources such as yearbooks and directories with long runs of annual volumes, whose value to the researcher multiplies if a theme or issue can be pursued through many years. A microfilm or digital image of the whole run of such sources is one obvious solution, but so far only certain categories such as statistical bulletins and population censuses have been reproduced in any comprehensive way.

Preliminary reflections upon reference sources in general must start with David stark dictum, 'the compilers of reference tools cannot be satisfied merely to aspire to being reasonably accurate, or even almost accurate. Rather they must attempt perfection, knowing that most users will be unable to distinguish what happens to be correct from that which happens not to be' (Henige 1979: 123). It is imperative also that the compiler of a reference work should provide clear and detailed indications of its scope and coverage: what is and is not included, what sources, both documentary and institutional, were used in the compilation, the cut off date for the currency of the information and so forth. Equally the compiler and publisher must realize that many users will never read the introduction or preface containing this information, however carefully written, and will go straight into the text of the source. The actual text, therefore, needs to be arranged and presented with the utmost clarity in order to encourage intuitive use: clear layout with imaginative typography, good running headings, liberal cross-references and clear indexes. With online sources the problem is even more acute: users will turn immediately to the search facilities offered and ignore anything else on the opening screen(s). I sometimes feel that the instruction: 'read the introduction and guidelines for use' should be present on every screen with an appropriate link.

Virtually all reference sources are derivative. Some may essay independent gathering of data, such as for example the circulation of a questionnaire in the compilation of a directory, but most are put together by seeking out information from existing sources. Being derivative does not, of course, invalidate a work. It is the intelligent selection, editing, reformatting and presentation of derived information for a particular group of users that makes a useful reference tool. It is essential, however, that the method of compilation and range of sources used are fully exposed, and that users are made specifically aware of potential anomalies, for example that apparently directly comparable statistics may have been gathered at different times for different countries. Many users will be satisfied if they find specific information that they are seeking in a single source: they need to be encouraged by reference librarians, and indeed by the sources themselves, to cross-check the information in other sources. 
Reference sources, on the whole, are not well served by reviews in the specialist Africanist journals. If treated at all, they will often be only in the 'shorter review' section with comments limited to little more than: 'researchers will be glad to note the appearance of a new edition of ....' Such summary treatment probably also discourages publishers of reference works, often expensive titles in small editions, from wide provision of review copies. The result is that there is often little real analysis of the merits, demerits and significance in relation to existing works of new publications, or re-assessments of continuing sources and new editions. Even where reviews are provided, opinions may be bland and uninformed. Gretchen Walsh (Walsh 2004) provides detailed examples of disparity between reviews of the same work in different sources, while Joe Lauer (Lauer 2006) voices the view that 'too many librarians are insufficiently critical when reviewing reference works' partly perhaps because these are often the products of their fellow professionals. Hans Zell in his African studies companion, $4^{\text {th }}$ ed., (Lochcarron: Hans Zell, 2006) sees the American Library Association's Choice and Standing Conference on Library Materials on Africa (SCOLMA)'s African research and documentation as the two professional journals carrying a fair range of reviews of Africanist reference works that are deemed the most useful and trustworthy by their fellow professionals, and his entries include references to all reviews in these two sources. In my Guide I try to include references to as wide a range as possible of available reviews in professional library, Africanist and subject specialist journals. However it should be remembered that reviews are really only going to be used by librarians in either their acquisition or reference advisory modes, and in the former there is an increasing feeling that today major library vendors' approval programmes are the principal influence on libraries' decisions to purchase (Hans Zell, personal communication). Readers who are unlikely to read the introduction to a reference work that they find on the shelves are even less likely to seek out reviews that may assess the work.

There is no space here to explore the whole range of relationships between the reference source and the user. Fortunately, this is done lucidly and at length in a recent paper by Gretchen Walsh, long Head of the African Studies Library at Boston University (Walsh 2004) which looks at the whole matter of the reference query: the approaches that researchers take to find their information, and the problems that are raised for them by variously the compilers, the publishers, the reviewers, the cataloguers, indexers and reference librarians, and the Internet. It is witty, wide-ranging, vastly informed, and unsparing of thoughtlessness and carelessness by any of those concerned.

Turning to the range of reference sources that I have examined over the last twenty years while compiling the two editions of my Guide and looking for patterns and characteristics, I see them as falling conveniently into three 'ages'. The 'First Age' includes titles published during the colonial period up to about 1960; the 'Second Age' comprises works published from about 1960 (i.e. basically post-independence for most African countries) to the beginning of the $21^{\text {st }}$ century, and the 'Third (or Present) Age' includes contemporary works produced since the Millennium. 
The First Age (publications to c. 1960)

As one might expect, this period is characterized particularly by general compendious sources produced by the various European colonial powers: compilations intended to provide background data for colonial administrators and their military and naval colleagues.

A particularly substantial resource is represented by the large and varied collection of volumes issued by the British War Office Intelligence Department (later Intelligence Division) from the 1870s up to the 1940s. For many regions of Africa, and not only those under British control, they provide the earliest examples of structured compilations of data. They are various labelled military reports, route books or handbooks, and, despite their military origin, provide a wide range of miscellaneous information on topography, communications, settlements, climate, trade, agriculture and natural resources, peoples and languages, history, administration. Some of these volumes, e.g. those for the Sudan associated with Lord Gleichen, are comparatively well known and available in libraries, but many others, initially printed in small numbers for official use and only made publicly accessible several years after publication, are often difficult to find. Indeed copies may only be available in the National Archives. Other official series produced by organs of the British government were the so-called Peace Handbooks created by the Foreign Office for the use of British delegates to the 1918-19 Paris Peace Conference and those produced by the Naval Intelligence Division of the Admiralty, of which the series of Geographical Handbooks produced during World War II are the best known, with substantial volumes for French West Africa (London, 1943-1944), French Equatorial Africa and Cameroons (London, 1942) and The Belgian Congo (London, 1944).

A whole family of volumes was produced by British colonial officers. Sometimes these were issued by the British or colonial governments, sometimes by commercial publishers, but in every case they were drawing on data collected by the colonial governments, and even where they appeared under a single author/editor they were often the product of the whole administration. In the period before World War I, there are the largescale compilations associated with Sir Harry Johnston, Commissioner in British Central Africa, 1891-1896, British Central Africa (London: Methuen, 1897); The Uganda Protectorate (London: Hutchinson, 1902) and Liberia (London: Hutchinson, 1906). Other examples are F.B. Archer's The Gambia Colony and Protectorate: an official handbook (London: Nelson, 1906; reprinted London: Cass, 1967) and H.R. Wallis's Handbook of Uganda (London: Crown Agents, 1913; $2^{\text {nd }}$ ed. 1920). Following World War I we have the Gazetteers of the Northern Provinces [of Nigeria] (Lagos: Government of Nigeria, 1921-1934) (12 volumes). These were reprinted (London: Cass, 1972) (4 volumes) with valuable notes on the series, the background to its compilation, and each individual title by Tony Kirk-Greene. Other examples are the Handbook of Sierra Leone (London: Grant Richards, 1925) by T.N Goddard, Assistant Colonial Secretary; The Handbook of Tanganyika (London: Macmillan, 1930) by G.F. Sayers, Assistant Secretary in the Chief Secretary's Office; and The Gold Coast 1931: a review of conditions (Accra: Census Office, 1931) by A.W. Cardinall, Chief Census Officer. Post1945 equivalents to these, produced in the last years of colonial rule, are J.P. Moffett's Handbook of Tanganyika (Dar es Salaam: Government of Tanganyika, 1958), a completely recast $2^{\text {nd }}$ ed. of Sayers above, this time building on a 
companion work emphasizing economic data by the same author, Tanganyika: a review of its resources and their development (Dar es Salaam: Government of Tanganyika, 1955) and, probably the last of its line and perhaps the most voluminous of them all, Handbook to the Federation of Rhodesia and Nyasaland (London: Cassell for Federation Information Department, 1960) compiled by W.N. Brelsford, the Director of Information of the Federation.

Wider in geographical sweep, but a product of the same curiosity to collect and analyse data, was the work of the African Research Survey, set up by the Royal Institute of International Affairs in 1931, which resulted in three largescale volumes, all issued by Oxford University Press in 1938: Lord Hailey's An African survey; E.B. Worthington's Science in Africa and S.H. Frankel's Capital investment in Africa. Helen Tilley makes the point that 'while Worthington's and Hailey's volumes were issued under their names alone, they were in truth the product of an extensive network of hundreds of experts' (Tilley, Helen, 'Ambiguities of racial science in colonial Africa; the African Research Survey ...,' in Science across the European empires, 1800-1950, ed. Benedikt Stuchtey, (Oxford: Oxford University Press, 2005, p. 257). The first two works of the trilogy were then optimistically revised after the Second World War hoping to provide guidance for a new generation of administrators: $A n$ African survey; revised 1956 (London: Oxford University Press for Royal Institute of International Affairs, 1957) and Science in the development of Africa: a review of the contribution of physical and biological knowledge South of the Sahara (London: CCTA \& CSA, 1958). Regional examples in the field of the biological sciences include David Bannerman's The birds of tropical West Africa (London: Crown Agents, 1930-1956) (8 volumes) and Flora of West Tropical Africa ( $1^{\text {st }}$ ed. London: Crown Agents, 1927-1936, 2 volumes; $2^{\text {nd }}$ ed. London: Crown Agents, 1953-1972, 3 volumes).

All the other colonial powers in Africa also produced a range of publications documenting their possessions (and sometimes neighbouring areas), either published officially by their governments or compiled by officers of the colonial administrations. For the French, Georges Bruel's L'Afrique équatoriale française: le pays, les habitants, la colonisation, les pouvoirs publics (Paris: Larousse, $1918 ; 2^{\text {nd }}$ rev. ed. 1935) is typical of earlier largescale volumes on individual regions. And French colonial effort culminated in the ten volume Encyclopédie de l'Afrique française (Paris: Éditions de l'empire français, 1940-1951). Germany might have lost her colonies by 1918 but continued to produce reference sources based on data collected during the colonial period such as the Deutsches Kolonial-Lexikon (Leipzig: Von Quelle \& Meyer, 1920) edited by Heinrich Schnee, former Governor of German East Africa, 1912-18. For Italy the official Guida amministrativa e delle attività economiche dell'impero Africa orientale italiana (Turin: Briscioli for Ministero della Cultura Popolare, 1938) was complemented by the commercial Africa orientale italiana (Milan: Touring Club Italiano (TCI), 1938). The largest-scale compilations by both the Belgian and Portuguese governments only appeared towards the end of the colonial period: Le dictionnaire colonial (Brussels: E. Guyot, 1950-51; $3^{\text {rd }}$ ed. 1955) and the Encyclopédie du Congo belge (Brussels: Bieleweld, 1950-1953); Império ultramarino Português (Monografia do Império), comp. Henrique Galvão \& Carlos Selvagem (Lisbon: Empresa Nacional, 1950-1953).

Throughout this 'First Age', reference works deriving from the official colonial presence were complemented by commercial sources. Allister 
Macmillan's The Red Book of West Africa: historical and descriptive, commercial and industrial facts, figures and resources (London: Collingridge, 1920) is well known and was reprinted by Cass in 1968, but he was also responsible for volumes on Mauritius (London: Collingridge, 1914; reprinted New Delhi: Asian Educational Services, 2000), on Eastern Africa and Rhodesia (London: Collingridge, 1930), and on a number of South African cities, locally published. Early works compiled by black Africans include J.A.O. Payne's Lagos and West Africa almanack and diary (London: J.S. Phillips, 1875-1894) and S.R. Wood (i.e. Kofi Esemotoo)'s Handbook of the Gold Coast for 1907 and 1908 (Manchester: Heywood, 1907). Locally published sources such as directories and yearbooks were often issued by the local press, such as the Cape Times (Cape Town), The Leader (Nairobi) and the Daily Times (Lagos). Shipping companies and airlines were encouraged to produce works as first emigration, and then tourism, to the colonies increased: Union Castle Line's South and East African year book E guide (London: 1893-1949) and Central African Airways guide to the Federation of Rhodesia and Nyasaland (Salisbury: 1957; $3^{\text {rd }}$ ed. 1961).

Are works produced during this 'first age' still likely to be of relevance today? Of course they are: the question would hardly be worth asking if it was not for libraries desperate for space-making proposals such as to relegate all sources published before 1950. 'One has only to realize how often historians return to Hailey's 1938 African survey, to appreciate how rapidly information which appears to be common currency slips into an oblivion whence it is hard to retrieve' (David Birmingham, Fournal of African History, 21, 1980, 139). Recent articles by P. Dagradi (Terra d'Africa, 10, 2001, 183-192) re-examining the Touring Club Italiano's Africa orientale italiana of 1938, and by M.R. Doormont (History in Africa, 33, 2006, 473-493) looking at biographical compilations for the Gold Coast by C.F. Hutchison (1927) and E.J. Sampson (1937) and referring frequently to The Red Book of West Africa (1920) noted above, both attest to continuing interest in revisiting such works. A number of significant early titles were reprinted in the 1970s and 1980s by firms such as Frank Cass, and some form of reprinting or digitization of many other titles, for example the British War Office and Admiralty series noted above, would be of immense benefit to scholarship.

\section{The Second Age (c. 1960 to 2000)}

The most obvious new feature of reference sources produced in the years post 1960 , compared with those in the preceding 'Age', is the widespread emergence, and soon the predominance, of sources produced in the USA. Mirroring the products of the European governments with colonies in Africa discussed above were the Area Handbooks, normally with one volume per country. These were originally designed to provide compilations of basic facts for use by United States military and diplomatic personnel in their relationships with the rest of the world. Compilation and editing were for many years undertaken by the Foreign Area Studies Division of the American University in Washington under contract to the US Department of the Army, with the first volume for an African country appearing in 1958. In 1978 the name of the series was changed to Country Studies: the intention of the change was to make the series appeal to a wider audience, and this often led to a significant reduction in the amount of detail in later editions. Earlier editions, 
therefore, remain valuable not just for their contemporary relevance but because they cover topics omitted from later editions. The Library of Congress Federal Research Division took over responsibility for the series in 1987, and the texts of all the volumes produced since then are also freely available online. No new volumes have appeared since 1998.

For locating topographic entities, the new standard source post 1955 became the Gazetteers issued by the United States Board on Geographic Names (USBGN) with volumes for individual African countries. All are now available online from the GEONET Names Server <http:/earth-info.nga.mil/gns/html/ index.html> maintained by the National Geospace-Intelligence Agency. Another major feature of the post-1960 world has been the compilation and publication of large quantities of data by international organizations: the United Nations and its agencies, especially the Food and Agriculture Organization (FAO), UNESCO, the World Bank and the International Monetary Fund (IMF). In Africa itself there is the work of the UN Economic Commission for Africa (ECA) and the African Development Bank (ADB). Economic, demographic and statistical data produced by these agencies, increasingly available online, are those on which other reference sources build: for example, the continuing commercial sources, Africa south of the Sahara (London: Europa, 1971- ) and Africa contemporary record (New York: Holmes \& Meier, 1969- ), which themselves then become quarries for compilers of one-off reference sources to mine for data.

During this period there emerged several largescale scholarly reference sources, authored principally by university staff, for which there is no real equivalent in the 'First Age'. Two major co-operative compilations associated with the International African Institute were the Ethnographic survey of Africa (London: International African Institute, 1950-1977) (60 volumes) and the Handbook of African languages (London: Oxford University Press for IAI, 19521959) (4 volumes). Two complementary sources covering the same field as each other but with differing approaches were the Cambridge history of Africa (Cambridge: Cambridge University Press, 1975-1986) (8 volumes) using 72 contributors, almost all from Europe and North America and the great majority from Britain and the USA, and the UNESCO general history of Africa.

(London: Heinemann/Berkeley, CA: University of California Press, 1981-1993) (8 volumes) employing over 350 authors, almost all from Africa.

Other publications with a 'colonial' flavour tend to look backwards at the personnel of empire: Tony Kirk-Greene's A biographical dictionary of the British Colonial Service, 1939-1966 (London: Hans Zell, 1991); the Biographie belge d'outre-mer/Biographie coloniale belge (Brussels: Académie royale des sciences d'outre-mer, 1948- ) and its interesting companion series Biographie historique du Congo (Lubumbashi: Université de Lubumbashi, 2000-2005) and the French Hommes et destins; dictionnaire biographique d'outre-mer. (Paris: Académie des sciences d'outre-mer, 1975-1989).

Among commercial publishers one of the most significant features of the 'Second Age' was the emergence of a specialist imprint almost solely concerned with Africanist reference sources. Founded by Hans Zell in 1975, Hans Zell Publishers was initially independent, then an imprint within a succession of larger publishers until 1997 when Bowker-Saur/Reed Reference Publishing terminated their agreement. During this period Zell published nearly 80 reference titles, attracting contributors from Europe, North America and Africa 
itself, and compiling a number of major sources himself. Many of his titles became immediate standard works and winners of professional awards, while several were published on behalf of leading institutions and associations such as the International African Institute and the Standing Conference on Library Materials on Africa (SCOLMA). The Africanist community worldwide quickly came to see the Zell imprint as a guarantee of quality, and its demise, lucidly described by Zell himself (Zell 2005), was a major blow as well as an eloquent comment on the increasingly minuscule market for specialist Africanist reference works. Zell himself continues to issue a handful of titles from his Highland fastness, including new editions of his own compilation, the African Studies Companion ( $4^{\text {th }}$ ed. Lochcarron: Hans Zell, 2006).

Returning to the US, many commercial reference sources for Africa emerged post 1960 to support area study programmes at US universities, US commercial interest in Africa and interest on the part of African-Americans in their roots. The African historical dictionaries, a series from Scarecrow Press edited overall by Jon Woronoff, commenced in 1974, provides a separate volume for each country, and continues to publish several volumes every year. A number of country titles are now in their $3^{\text {rd }}$ or even $4^{\text {th }}$ editions and continue to be revised, and the whole corpus amounts to well over 120 volumes. In some cases new editions omit coverage of topics present in earlier editions, and as with the Area Handbooks all editions need to be retained and consulted. No series of reference works has received fiercer criticism than this, beginning with the classic assessment by David Henige, 'African historical dictionaries: through the looking glass' (Henige 1979). Lack of balance and lack of overall editorial control, and the absence of cross-references and indexes, have all been singled out. Equally, however, some recent reviews have been favourable, although it can be alarming to see that some libraries put little else on Africa on their open reference shelves other than the Scarecrow series. Of wider significance is that the critical and much debated reviews of volumes in the 1980 s led journal editors to ensure that new volumes received reviews, and probably ensured that a wider range of other Africanist reference sources was also reviewed. The reviews of this series are discussed in general in my Guide, pp. xlii-xliii.

Scarecrow Press, of course, is a large concern and publishes reference sources in many fields, and a number of other US publishers with large reference lists have devoted attention to Africa, often with a volume for Africa within a multivolume source covering the world. As activity in other sectors of African reference work publishing in the 'Second Age' was declining, such publishers remained prepared to issue titles in the 1990s and early years of the new century, including volumes from McFarland, Pan-African chronology (Jefferson, NC: 1990-1999) (3 volumes) and African states and rulers, $2^{\text {nd }}$ ed., (Jefferson, NC: 1999); Greenwood Press, African studies thesaurus (Westport, CT: 1992), The peoples of Africa: an ethnohistorical dictionary (Westport, CT: 1996) and The Greenwood encyclopedia of women's issues worldwide. Volume 6, Sub-Saharan Africa (Westport, CT: 2003); Facts on File, Encyclopedia of African nations and civilizations (New York: 2002) and Encyclopedia of African history and culture (New York: 2005) (5 volumes); Garland, Garland encyclopedia of world music. Volume 1, Africa (New York: 1998) and Charles Scribner's Sons, The Encyclopedia of Africa south of the Sahara (New York: 1999) (4 volumes). Many of these were addressed to the high school/undergraduate market which appears to remain buoyant, and although some were well received, especially the last 
title, a number of the other examples cited above attracted adverse reviews (see references to reviews in entries in my Guide, and Walsh, 2004, especially pp. 58-60).

In Africa itself, independence was initially marked in many countries by a burst of publishing of commercial and trade directories demonstrating economic hope for the present, and of chronologies and historical and biographical dictionaries often emphasizing either the pre-colonial past or the more recent years of the independence movements. Statistical sources attempted to continue those of the colonial period. Some largescale projects such as atlases and botanical floras which had begun publication in the colonial period were completed, often with the continuing involvement of European agencies, e.g. the Atlas du Cameroun (Yaoundé: Institut de Recherches Scientifiques and Paris: ORSTOM, 1956-1975). By the late 1980s and 1990s, however, economic realities in most of Africa had not only made it impossible to think of producing new titles or new editions, but had also brought many continuing sources to a halt.

The Republic of South Africa is, of course, an exception. Always very conscious both of its historical, geological and biological past, and its political present, South Africa has not only a most impressive and continuing range of published reference sources, it also has one of the most assiduous of chroniclers in Reuben Musiker whose Guide to South African reference books, $6^{\text {th }}$ ed., (London: Mansell, 1997) is only the most recent of his bibliographical surveys which began in the 1950s. In South Africa both the government and publishers have always been ready to support editorial teams in long-term preparation of what they deemed to be significant largescale reference works. Examples are the twelve volume Standard encyclopedia of Southern Africa (Cape Town: NASOU, 1970-1976); the four volume South African music encyclopedia (Cape Town: Oxford University Press for Human Sciences Research Council, 1979-1986), the five volume Dictionary of South African biography (Pretoria: Human Sciences Research Council, 1968-1987), succeeded by the New dictionary of South African biography (Pretoria: 1995- ) and A Dictionary of South African English on historical principles, ed. Penny Silva et al., (Oxford: Oxford University Press in association with the Dictionary Unit for South African English (DSAE), 1996). A huge work still in progress is the Suid-Afrikaanse geslagregisters/South African genealogies (Stellenbosch: Genealogical Institute of South Africa, 1986- ), with volume 12 appearing in 2005. In South Africa too, reference works, once they have established themselves as standards, tend to be kept up-to-date in new editions. Roberts'birds of Southern Africa, $7^{\text {th }}$ ed., (Cape Town: Trustees of the John Voelcker Bird Book Fund, 2005) originally appeared in 1940, while The mineral resources of South Africa, $6^{\text {th }}$ ed., (Pretoria: Council for Geoscience, 1998) was first published in 1930.

\section{The Third (or present) Age and the Future}

A small place obviously still remains for the traditional, detailed, scholarly printed reference source with a leisurely publishing schedule. A classic in the making is the Encyclopaedia Aethiopica: a reference work on the Horn of Africa, ed. Siegbert Uhlig, (Wiesbaden: Harrassowitz, 2003- ) with 5 volumes projected for completion by 2009. Each volume contains some 1,000 articles by over 250 contributors. A contemporary touch is added by the project's website, $<$ http://www.rrz.uni-hamburg.de/EAE/>, which contains addenda and 
corrigenda to the published volumes. Of similarly thorough scholarly coverage are the relevant volumes of the Handbuch der Orientalistik, Abteilung 1. Der Nahe und der Mittlere Osten, Bd. 13, Arabic literature of Africa, ed. J.O. Hunwick \& R.S. O'Fahey, (Leiden: Brill, 1994-2003) (4 volumes). Other works continue to be cast in a traditional mould because they began publication many years ago and are not yet complete: for example, the Dictionary of Mauritius biography (Port Louis: Société de l'histoire de l'Île Maurice) that commenced publication in 1941 and had reached Fasc. 56 by 2003. Into this category come a number of the largescale floras, botanical reference sources often commenced in the colonial period and still working their way slowly forwards, usually the result of a co-operative effort by overseas institutes and botanical institutes in African countries. The Royal Botanic Gardens, Kew, for example, is currently involved in the continuing compilation and publication of both the Flora of tropical East Africa which commenced in 1952 and Flora Zambesiaca which began publication in 1960. The Muséum national d'Histoire Naturelle in Paris is leading the editorial work on the Flore de Madagascar et des Comores, still incomplete after begining publication in 1936.

However, the $21^{\text {st }}$ century approach to organizing large quantities of botanical information rather than a continuing series of printed volumes is represented by online undertakings such as the 'Database of the flowering plants of Africa south of the Sahara', <http:/www.ville-ge.ch/cjb/bd/africa/ index.php $>$, which is in the process of digitizing data from the printed Énumération des plantes à fleurs d'afrique tropicale (Geneva: 1991-1997), and Plants of Southern Africa: an annotated checklist (Pretoria: National Botanical Institute, 2003) with other printed sources scheduled to be incorporated. The 'African Plants Initiative (API)', again with the Royal Botanic Gardens, Kew involved, is another massive database in the making, digitizing images and descriptions from a number of published floras and releasing its first online content in January 2007 (see <http://www.aluka.org/page/content/plants.jsp>). Regional counterparts include Plants of Southern Africa (POSA), an online checklist (<http://www.nbi.ac.za/frames/infofram.htm. $>$ ) and The interactive flora of Southern and Southern Tropical Africa (<http://www.flora.sanbi.org/ its_page?comID =2>), both associated with the South Africa National Biodiversity Institute (SANBI) in Pretoria.

Like these examples, more and more reference sources are coming online. Most of the relevant sources associated with bodies like the United Nations and its agencies are now available online as well as (at present) in printed form. The Area handbooks/Country studies and the USBGN Gazetteers, both discussed above, are all available online, and new compilations are likely to be available online only. Statistical and demographic sources from African countries themselves, where they are maintained at all, are increasingly online. Online sources, of course, still have to be maintained and updated. The African Music encyclopedia <http://africanmusic.org> has completed less than half the entries it originally proposed and appears not to have been updated for at least 5 years, while the African governments on the WWW site (<http://www.gksoft.com/ govt/en/africa.html $>$ ) has not been updated since 2002. Offering online versions of printed sources does not necessarily produce a direct equivalent. Europa Publishers' annual Africa south of the Sahara remains available in print as a discrete source, but is available online only as part of the much larger (and more expensive) package Europa World Plus. One problem of reference 
sources being regularly updated online which is often overlooked is that the earlier 'edition' vanishes as data is electronically edited, and the chance to follow themes through successive editions is lost along with the text of those earlier 'editions'.

As Hans Zell (Zell 2005) makes clear, the market for specifically Africanist reference sources continues to decline. His own compilation, the African studies companion, sold over 1,200 copies in its first edition of 1989, just over 800 in its $2^{\text {nd }}$ edition of 1997 , just over 300 copies of the $3^{\text {rd }}$ edition of 2003 , and only 200 copies to date of the $4^{\text {th }}$ edition a year after publication in May 2006 (Hans Zell, personal communication, 2007). This is for what is now an established source and despite continually expanding content and consistently laudatory reviews. The first and second editions, of course, benefited from the publicity and distribution network of the publishing conglomerate of which the imprint was part. The third and fourth editions have been also been available in regularly updated online versions free to those who purchase the printed edition, but Zell reports that he has found the uptake of the online option surprisingly low, despite the fact that online access is bundled with print.

Joe Lauer, Africana Librarian at Michigan State University, has a trenchant piece, 'Reference works as false idols' in the 'Curmudgeon's corner' column of the Africana libraries newsletter, 119, 2006 (Lauer 2006) in which he sees too much time spent on compiling needless reference works, as well as too much money spent by libraries on acquiring reference materials, in addition to making the more familiar criticisms of too much credence being given to the content of reference works and the lack of critical reviews. The point about emphasizing reference sources that are really needed, rather than those that are easy and cheap to compile, has been addressed several times by the US Africana Librarians Council (publishers of the Newsletter), and their 'Bibliographies and other reference works which need to be updated' list, originally compiled by Nancy Schmidt in 1993, is available on their website (Africana Librarians Council 2007). Other than bibliographies, the emphasis in this list is on directories of institutions, and on guides to statistical sources. Zell (Zell 2005) agrees that new editions of directories of African studies institutions and research organizations are badly needed, and adds a note about the lack of revised editions of largescale biographical sources. I myself would add the absence for most African countries of up-to-date national atlases.

Publication of conventional reference sources in Africa itself seems to have largely dried up in the $21^{\text {st }}$ century. My searches for inclusion in my Guide turned up only a handful of imprints dated 2000 and later. As always, South Africa is the exception, with Tom Lodge's Compendium of elections in Southern Africa (Johannesburg: Electoral Institute of Southern Africa, 2002) being an outstanding recent example, while the SABONET (South African Botanical Diversity Network) Project (1996 to 2005) has produced at least a dozen botanical checklists for Southern African countries post 2000.

Perhaps the future, or at least part of it, lies with what, at present, is still unconventional: Wikipedia, the multilingual web-based free content encyclopedia which anyone can edit. Since its creation in 2001, Wikipedia has grown rapidly into one of the largest reference sites on the internet, and there is much African content: see <http://en.wikipedia.org/wiki/Africa> and follow the links to get a full idea of the sprawling nature of the phenomenon. WikiProject Africa has as some of its goals: 'Improve Wikipedia's coverage of Africa; 
Improve Africa-related articles, making them more informative and better written' (<http://en.wikipedia.org/wiki/Wikipedia:WikiProject_Africa>, accessed 30 May 2007). In July 2006 it was reported that there was at least some Wikipedia content in no fewer than 38 African languages $(<$ http:// digitalafrica.blogspot.com/2006/07/african-languages-and-wikipedia.html>). Reaction to Wikipedia from the online public appears overall to be very enthusiastic, and it is increasingly noticeable that any Google search on a topic will return an appropriate Wikipedia article near the top of the list of hits. Reaction, in contrast, from the professional Africanist community - academics and librarians alike - has run the gamut from a cautious welcome to unbridled scorn for the concept of a reference work that has not undergone the normal intellectual processes of review by editors and publishers. Every few months the Africanist discussion lists return to look at the phenomenon. Entering the keyword Wikipedia on the H-Africa discussion network (<http:// www.h-net.org/ africa/>) throws up some 40 contributions from 2005 to 2007. As so often, I feel that Gretchen Walsh, whose untimely death was reported as this volume was going to press, has made the most sensible comments in her contribution to 'Curmudgeon's corner' in the Africana libraries newsletter (Walsh 2006) where she sees that 'there is no need for Wikipedia. Standard publications do the job better', but that 'since it's already here ... we can't get rid of it. We can work to make it better'.

\section{References}

Africana Librarians Council. 'Bibliographies and other reference works which need to be updated', <http://www.loc.gov/rr/amed/afs/alc/bibpr.html>, consulted May 2007.

Henige, David (1979) 'African historical dictionaries: through the looking glass', Africana journal, 10, 120-128.

Lauer, Joe (2006) 'Reference books as false idols', Africana libraries newsletter, 119.3pp. <http://www.indiana.edu/ libsala/african/ aln 119carmudgeon.html>.

Limb, Peter (2006) 'African studies bibliography: a state-of-the art review', Africa bibliography 2005 (Edinburgh: Edinburgh University Press), pp. vii-xv.

McIlwaine, John (2001) 'Plus ça change: four decades of African studies bibliography', Africa bibliography 1999 (Edinburgh: Edinburgh University Press), pp. vii-xix.

Walsh, Gretchen (2004) " "Can we get there from here?" Negotiating the washouts, cave-ins, dead ends and other hazards on the road to research on Africa', pp. 5-96 in Research, reference service and resources for the study of Africa, ed. Deborah M. Lafond \& Gretchen Walsh (Binghamton, NY: Haworth Press. Published simultaneously as Reference librarian, 87/88, 2004).

Walsh, Gretchen (2006) 'Wikipedia: can we beat it? Should we join it? Is it the end of the world as we know it?', Africana libraries newsletter, 118. 2pp. $<$ http://www.indiana.edu/ libsala/african/aln118carmudgeon.html>.

Zell, Hans (2005) 'The perilous business of reference publishing in African studies', pp. 199-226 in Africanist librarianship in an age of change, ed. Victoria K. Evalds \& David Henige (Lanham, MD: Scarecrow Press). 